\title{
WHAT HAVE WE LEARNED ABOUT Ocean Variability FROM SATELLITE OCEAN COLGR IMAGERS?
}

\author{
BY JAMES A. YODER AND MAUREEN A. KENNELLY
}

Almost 20 years ago, Oceanography published a short article entitled, "Satellite Ocean Color-Status Report"

(Yoder et al., 1988). The article pointed out that the Coastal Zone Color Scanner (CZCS) was launched 10 years previous and that during the subsequent years, the focus of the ocean color community was on understanding what the instrument was actually measuring, learning the limitations of the measurements, and developing techniques and methods to improve the accuracy and increase applications. The article concluded, "The next 10 years should see a large increase in the number of investigators, research programs and publications which take advantage of this important new data source for oceanography". That remark has certainly proved to be accurate, and imagery from CZCS, OCTS (Ocean Color and Temperature Sensor), SeaWiFS (Sea-viewing Wide-field-ofview Sensor), MODIS (Moderate-resolution Imaging Spectrometer) and other satellite ocean color sensors are now being used for many applications in ocean science.

The purpose of this article is to discuss results related to one common application of the imagery—quantifying near-surface variability related to biological and biogeochemical processes at spatial scales ranging from about $1 \mathrm{~km}$ to the global ocean, and at time scales ranging from about 1 day to interannual. Figure 1 illustrates a 7-year (1997-2004) global climatology of SeaWiFS-Chl ("Chl" will be used hereafter to refer to chlorophyll $a$ concentration as calculated from satellite measurements), as well as images of maximum and minimum values for each pixel in the mean image (after Yoder and Kennelly 2003 and similar to that produced by Gregg et al., 2005). Note that the overall pattern in all three images is similar, with low chlorophyll concentration in the gyres and comparatively higher mean values for the ocean margins, Equatorial Pacific and at latitudes greater than $40-45^{\circ} \mathrm{N}$ or S. In Figure 1, the difference between the maximum and minimum image is a simple measure of the variability associated with each pixel in the mean image, and explaining such variability, as well as assigning it to the appropriate time scale, is the topic of this article. 

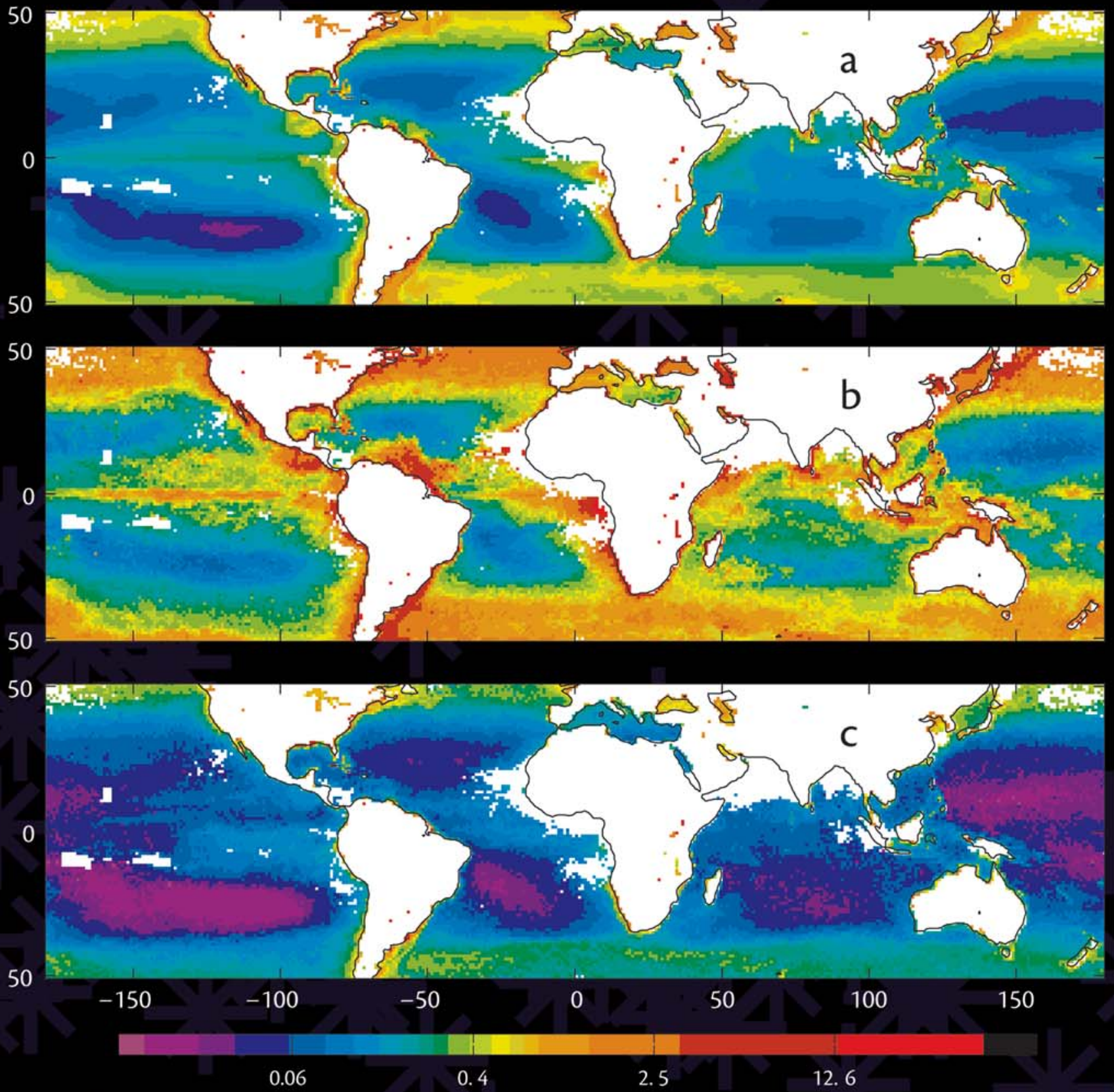

Figure 1. SeaWiFS seven-year global (a) mean, (b) maximum, and (c) minimum $\mathrm{Chl}\left(\mathrm{mg} \mathrm{m}^{-3}\right)$ images. Color bar indicates Chl, and "white" indicates areas of insufficient observations owing to high cloud cover. 
This article is written in the style of a review, and is focused on how satellite ocean color imagery has contributed to understanding variability related to biological and biogeochemical processes within five important themes: (1) seasonal cycles; (2) effects of the El NiñoSouthern Oscillation (ENSO), (3) other interannual variations, (4) mesoscale and high-frequency variability, and (5) longterm trends. For convenience we will illustrate the main points using figures based on the ocean color research conducted at the University of Rhode Island.

\section{PROCESSING OCEAN COLOR IMAGERY}

One goal of ocean color remote sensing is to determine the concentration of phytoplankton chlorophyll $a$ and of other molecules and particles in near-surface ocean waters. The traditional focus has been on Chl owing to its importance as an index of phytoplankton biomass concentration, the role of chlorophyll $a$ as the most important pigment involved in photosynthesis, and because $\mathrm{Chl}$ and its derivation products are generally the dominant absorbing molecules, other than water itself, in open-ocean waters. A simplified description of the most common approach for measuring water

James A. Yoder (jyoder@whoi.edu) is Professor of Oceanography, Graduate School of Oceanography, University of Rhode Island, Narragansett, RI, USA and is currently Vice President for Academic Programs and Dean, Woods Hole Oceanographic Institution, Woods Hole, MA, USA. Maureen A. Kennelly is Marine Research Specialist, Graduate School of Oceanography, University of Rhode Island, Narragansett, RI, USA. optical properties from satellite sensors, including Chl, is briefly described below.

Some of the sunlight (spectral irradiance) reaching the surface of the ocean penetrates the air-sea interface into ocean waters. Open-ocean waters absorb red photons (those with wavelengths near $700 \mathrm{~nm}$ ) much more strongly than blue photons (those with wavelengths near $400 \mathrm{~nm}$ ), and water molecules scatter photons of blue light in all directions, including back out of the water, more readily than for red photons. Other dissolved and suspended substances and particles, including phytoplankton cells, marine detritus and some dissolved organic matter also have wavelength- dependent absorption and scattering properties. As a result, the spectrum of the light scattered back out of the ocean contains information about the dissolved and suspended constituents in the water.

Photons that enter the water, and then scatter back out of the water, comprise the emergent flux, generally referred to as the "water-leaving radiance" or "reflectance" (reflectance is proportional to water-leaving radiance normalized by incident irradiance). Figure 2 shows the idealized change in water-leaving radiance/reflectance spectra as $\mathrm{Chl}$ increases in open-ocean waters. Simple Chl algorithms, such as those used for virtually all of the results discussed in

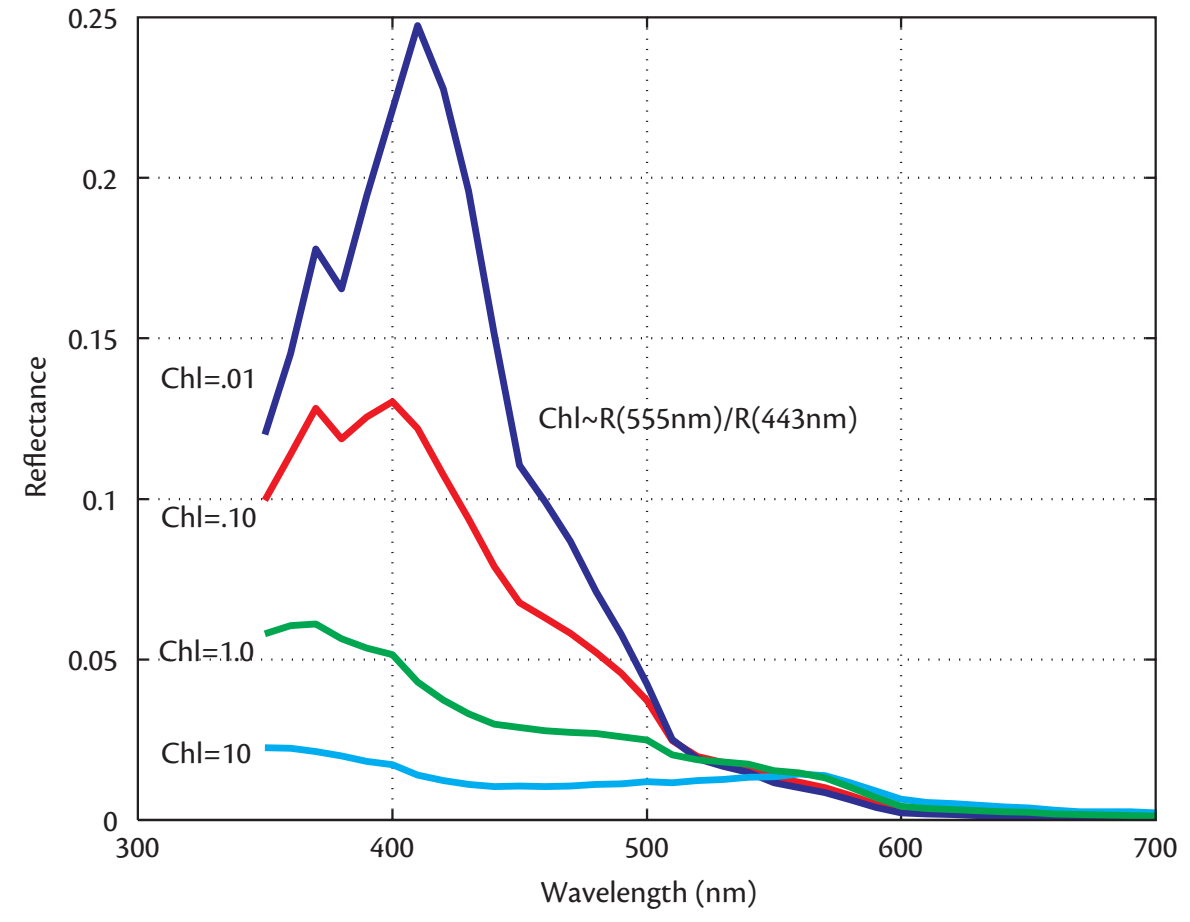

Figure 2. Idealized reflectance (which is similar to water-leaving radiance) spectra at different concentrations of chlorophyll $a$ in waters where phytoplankton and water are the primary contributors to bio-optical properties. Standard algorithms calculate chlorophyll $a$ concentration (Chl) based on the ratio of green-band-to-blue-band reflectance (or waterleaving radiance). 
this article, are based on the ratio of the water-leaving radiance (or reflectance) at a narrow (ca. $10 \mathrm{~nm}$ wide) blue or blue-green wavelength band centered in the 440-520 $\mathrm{nm}$ range to that of a green wavelength band centered in the 550-560 nm range. Simply stated, the water-leaving radiance at the blue wavelength is inversely proportional to Chl. The depth interval most affecting the water-leaving radiance extends from just below the surface to the depth equivalent to the inverse of the attenuation coefficient for downwelling spectral irradiance (K, with units of $\left.\mathrm{m}^{-1}\right)$. The depth of $1 / \mathrm{K}$ can be $50 \mathrm{~m}$ or more in the clearest ocean waters but is much shallower in waters with elevated chlorophyll (or other absorbing materials).

There are of course many factors and phenomena that affect the accuracy of Chl derived from satellite ocean color measurements. For example, satellite ocean color observations are only possible under low cloud or cloud-free conditions. Thus, clouds affect coverage statistics, and observations of the ocean only under low-cloud or cloud-free conditions is a potential bias. Even under cloud-free conditions, most of the signal observed from satellite altitudes over the ocean at the wavelength bands important for determining $\mathrm{Chl}$ originates from scattering and absorption in the atmosphere. Thus, accurate removal of the contribution of the atmosphere ("atmospheric correction") to the spectral radiance measured by a satellite sensor observing the ocean is essential for remotely determining water optical properties. On the ocean margins and particularly near the coast, the optical properties of the water become increasingly complex owing to suspended sediments, dissolved and particulate organic matter discharged with river water, and in the case of shallow waters, the contribution of bottom reflectance. These and other factors such as white caps, sun glint, and low sun angles during winter months at mid to high latitudes make processing extend over many consecutive days or weeks during some particularly cloudy seasons. Missing data and irregular spacing of valid Chl values make it difficult to apply sophisticated statistical techniques to analyze time and space patterns of daily images.

Composite images are used to over-

\section{...ocean color imagery provides a new window on upper-ocean variability related to biological and biogeochemical processes...}

global satellite data much more complex than implied by the simple description above. At some locations (and exactly where and when is difficult to determine without in situ measurements, although coastal waters within a few kilometers of the coast are particularly problematic) simple band-ratio algorithms fail to yield accurate Chl.

Following atmospheric correction, daily images of the derived products such as water-leaving radiance and $\mathrm{Chl}$ are then generally mapped to standard map projections. For any given study of temporal and spatial variability, each map (image) in the time series generally covers exactly the same region. Depending on the map projection, each pixel (a pixel is the smallest data element within a satellite image) in the mapped images can represent the same amount of ocean area. Mapped images can be treated as a matrix time series, although daily images (matrices) will have many elements with no Chl data primarily owing to cloud cover. For most parts of the global ocean, periods of no coverage can come some of the problems caused by irregular spatial and temporal coverage. Image compositing averages all pixels within specific image subareas, for example, averaging all $1 \times 1 \mathrm{~km}$ pixels within a $9 \times 9 \mathrm{~km}$ area of interest, to yield a new image having single values for new and larger pixels ( $9 \times 9 \mathrm{~km}$ in this example). Alternatively, all pixels representing every location (area) within an image time series and having valid data collected during a specific time interval (e.g., week or month) are averaged to yield weekly (or monthly) composite images. Compositing will, of course, limit the temporal and spatial scales that can be studied. For example, the effects of individual ocean eddies are generally not resolved in most composite images, although their average effect may be captured. Furthermore, the number of observations will often differ significantly for each pixel of a composite image, as cloud cover is not uniformly distributed over the ocean. Compositing is thus a method to achieve better temporal and spatial coverage but at reduced temporal and spatial resolution. 


\section{SEASONAL CYCLES}

Seasonal plankton cycles at mid to high latitudes $\left(\sim>45^{\circ} \mathrm{N}\right.$ or $\left.\mathrm{S}\right)$ are traditionally viewed as one of the most important sources of biological and biogeochemical variability in the ocean. In particular, the importance of the "spring bloom" (a period of rapid phytoplankton biomass increase from low winter levels) is a fundamental tenet of marine ecology, in part because many of the first quantitative plankton studies occurred at mid to high latitudes in European or North American waters where spring blooms are common in coastal waters (e.g., Riley, 1947; Sverdrup, 1953). Although seasonal plankton cycles were well established by in situ observations in coastal waters of Europe and North America, satellite ocean color observations provided the first synoptic view of seasonal phytoplankton biomass (Chl) cycles at regional to global scales and provided a new perspective on seasonal phytoplankton biomass variability

\section{Coherence in the Latitudinal}

\section{Shifts of Seasonal Pattern}

The first published composite image showed the spring bloom (May, 1982) in the North Sea and North Atlantic (Esaias et al., 1986). For CZCS, and then later for SeaWiFS and other sensors, monthly climatologies were produced by averaging monthly images from multiple years (Feldman et al., 1989; McClain et al., 1998). These monthly climatologies were in effect the first view of the mean pattern of seasonal phytoplankton biomass cycles on a global ocean scale. Campbell and Aarup (1992) used monthly mean Chl imagery to show the northerly seasonal migration of the spring bloom in the North Atlantic and used the differences in $\mathrm{Chl}$ between consecutive months as a minimum estimate of new production. Yoder et al. (1993) showed that the seasonal patterns in the images for large regions of the ocean were familiar to oceanographers

\section{...satellite ocean color observations provided the first}

\section{synoptic view of seasonal phytoplankton biomass (Chl)}

cycles...and provided a new perspective on seasonal

\section{phytoplankton biomass variability in the global ocean.}

in the global ocean. The most important contributions of ocean color imagery to understanding seasonal variability are: (1) showing coherence of the latitudinal shifts in seasonal patterns over large areas of the global ocean and (2) demonstrating the differences between the Southern Ocean and the Northern Hemisphere ocean basins. who studied seasonal plankton cycles in coastal waters and were coherent over large regions of the global ocean. For example, subtropical waters had approximately two times higher $\mathrm{Chl}$ in winter than in summer, whereas subpolar waters generally showed a two-peak seasonal cycle with spring and fall maxima and with summer and winter minima- both of these patterns were explained by some of the first models of plankton dynamics (e.g., Cushing, 1959).

Many of the seasonal features observed in regional- and basin-scale analyses were put into a global ocean perspective from the results of empirical orthogonal function calculations applied to a four-year time series of eightday composite global images $\left(50^{\circ} \mathrm{N}\right.$ to $50^{\circ} \mathrm{S}$ ) that had been averaged over time and space (Yoder and Kennelly, 2003). Similar results were obtained by analyzing a seven-year version of the original time series. In the seven-year time series, the two highest modes accounted for 45 percent of the total variability. Mode 1 (37 percent variance explained [PVE]) (Figure 3) showed that subtropical waters $\left(20^{\circ}\right.$ to $40^{\circ} \mathrm{N}$ or $\left.\mathrm{S}\right)$ had seasonal maxima in winter and minima in summer, whereas subpolar waters $\left(>40^{\circ} \mathrm{N}\right.$ or S) had spring or summer maxima and winter minima. Mode 2 (8.7 PVE) added additional seasonal effects, including the spring bloom in subpolar waters, particularly in the North Atlantic. These results, as well as those of others (e.g., Dandonneau et al., 2004) who analyzed multiple-year Chl image time series, confirmed that climatological monthly mean images give a reasonable picture of mean seasonal Chl cycles in the global ocean. In other words, interannual variability in the timing and magnitude of seasonal Chl cycles is sufficiently low, and the spatial coherence is sufficiently high, that averaging (compositing) over time and space does not significantly distort the main seasonal patterns.

Imagery from one or more satellite ocean color scanners have been used to study seasonal Chl cycles at regional 
EOF 1: $36.6 \%$

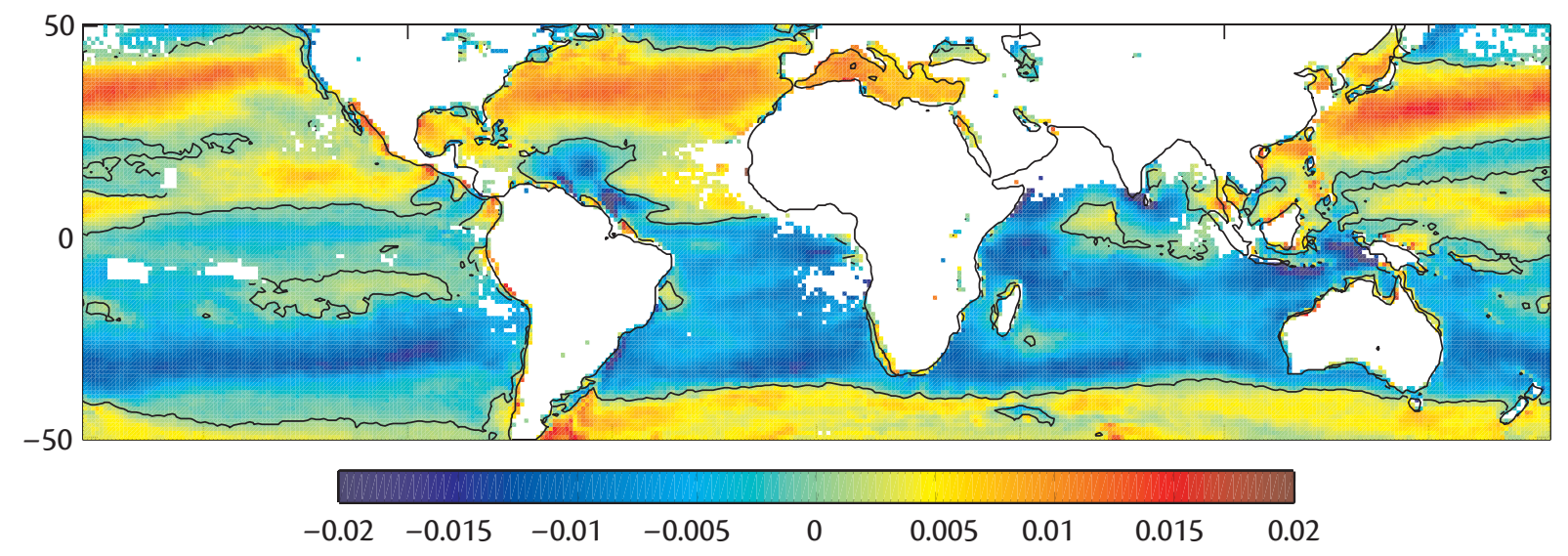

Amplitudes for Mode 1

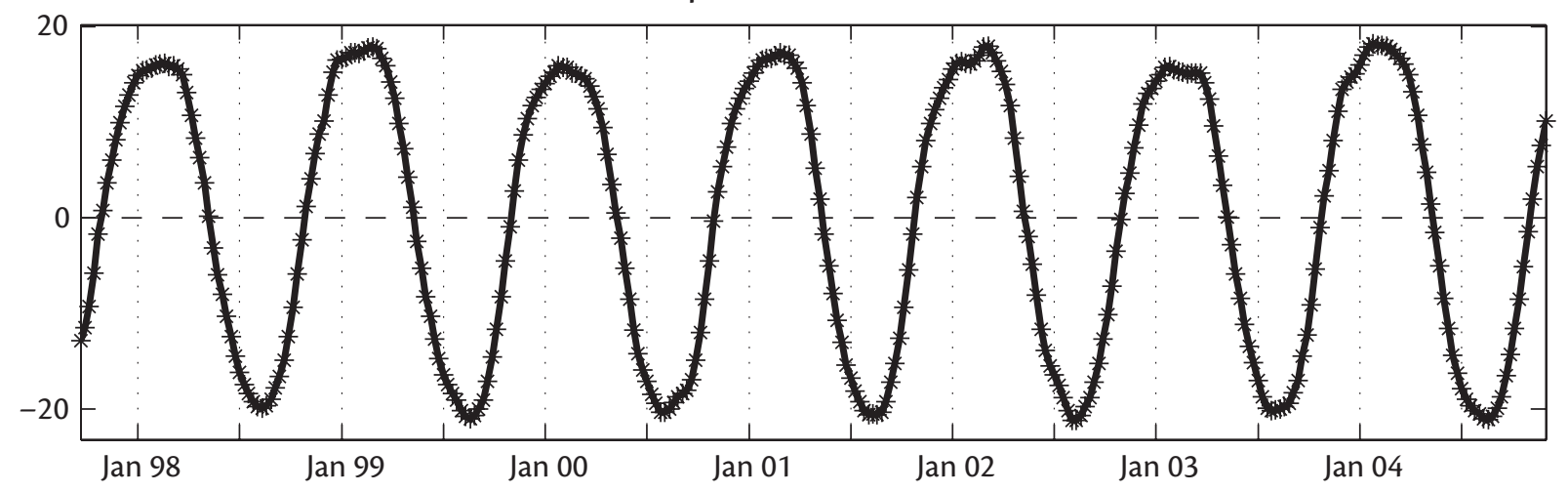

Figure 3. Mode 1 spatial pattern and amplitude time series from EOF (empirical orthogonal function) analyses. This mode (dominated by seasonal cycles) explains 36.6 percent of the variance in a seven-year time series of eight-day composite Chl deviation images (i.e., the seven-year mean image shown in Figure 1a was first subtracted from each image of the time series). At any time and for any pixel in the image, the signed magnitude of the deviation from the seven-year mean $\mathrm{Chl}$ is the product of the amplitude value in the time series and the pixel value in the spatial pattern. Figure and data processing are similar to that described by Yoder and Kennelly (2003).

scales $($ ca. $1000 \mathrm{~km})$ in many parts of the global ocean. Seasonal cycles have different forcing depending on the region. For example, the spring-summer blooms in subpolar waters are related to winter mixing that replenishes surface waters with nutrients. Winter mixing is followed by spring-summer increases of incident solar irradiance and watercolumn stratification leading to a welllit, initially nutrient-rich mixed layer conducive to phytoplankton growth and biomass increase. Winter blooms in subtropical waters are also responses to winter mixing, although mixing in the subtropics is generally weaker than that which occurs farther poleward. In the subtropics, comparatively high winter solar irradiance at the lower latitudes and shallow mixed layers leads to an immediate phytoplankton response (winter blooms) to nutrients. Analyses of region- al imagery, supported by in situ data and other information, allows one to sort out the different physical forcings and their respective effects on seasonal Chl cycles. Examples from the East and Gulf Coasts of North America are discussed.

Off the east coast of North America (and elsewhere), seasonal bloom characteristics are often related to seasonal changes to incident solar irradiance and stratification. In comparatively shallow 
shelf waters ( $<50 \mathrm{~m}$ depth) of the MidAtlantic Bight (MAB) and along coastal margins and shallow banks in the Gulf of Maine (GOM), Chl reaches seasonal maxima during winter and minima during summer (Yoder et al., 2001, 2002; Thomas et al., 2003, 2004) (Figure 4). lina (ca. 33 to $36^{\circ} \mathrm{N}$ ), the seasonal cycle accounts for more than 80 percent of the variability in monthly composite CZCSChl images in a 59-month time series (1981-1986) (Barnard et al., 1997). Highest Chl occurred during colder months of the year (ca. November through March)

\section{Satellite Chl imagery has also contributed significantly to quantifying seasonal variability of coastal upwelling systems.}

Winter peaks occur in comparatively shallow shelf waters at mid latitudes (ca. $35^{\circ}$ to $45^{\circ} \mathrm{N}$ ), because the depth of mixing is constrained by bottom depth, and solar irradiance is sufficiently high even during winter at these latitudes such that phytoplankton growth in the water column exceeds whatever threshold is required to sustain high biomass levels. This is not the case, however, for deeper slope and basin waters of the MAB and GOM, and for higher latitudes (e.g., Gulf of St. Lawrence). In these regions, seasonal blooms do not occur until stratification shoals the mixed layer, and that process occurs in spring-early summer depending on latitude. In the MAB's Slope Sea and in deeper waters of the GOM, peak Chl occurs during spring and fall and with winter and summer minima (Ryan et al., 1999; Yoder et al., 2001, 2002; Thomas et al., 2003; Schollaert et al., 2004). Farther to the north in the Gulf of St. Lawrence, seasonal Chl peaks occur in summer (Fuentes-Yaco et al., 1997). South of the MAB in subtropical coastal and shelf waters off North Caro- with mean Chl about two times higher than from June through September. In contrast, seasonal Chl variations are synchronous throughout the basin at the comparatively low latitudes $\left(<30^{\circ} \mathrm{N}\right)$ of the Gulf of Mexico, with peak Chl occurring from December to February (i.e., when mixing is strongest as evidenced by the depth of the mixed layer) (MullerKarger et al., 1991). Lowest Chl in the Gulf of Mexico occurred from May to July when the water column is most stratified (Muller-Karger et al., 1991).

Satellite Chl imagery has also contributed significantly to quantifying seasonal variability of coastal upwelling systems. Some of the first CZCS studies of upwelling in the California Current system off the west coast of North America showed that $\mathrm{Chl}$ co-varied with upwelling-favorable wind events during the summer upwelling season, and that filaments of upwelled waters containing high $\mathrm{Chl}$ extended several hundreds of kilometers offshore (Abbott and Zion, 1987; Michaelsen et al., 1988) (see Figure 5). Analyses of the entire CZCS image data set for the California Current region showed a semi-permanent across-shelf frontal zone near $32^{\circ} \mathrm{N}$ as evidenced by $\mathrm{Chl}$ gradients between 0.5 and $1.0 \mathrm{mg} \mathrm{m}^{-3}$ (Thomas and Strub, 1990). There was a pronounced seasonal cycle north, but not south, of the front with peak Chl during the summer. Chl increases began in March to April off southern California (ca. $\left.35^{\circ} \mathrm{N}\right)$ and progressed north during summer with development of upwelling favorable winds and wind stress curl (Strub et al., 1990; Thomas and Strub, 1990). Off California, a band of high Chl $\left(>2 \mathrm{mg} \mathrm{m}^{-3}\right)$ extended more than $200 \mathrm{~km}$ offshore from May through June, coincident with the seasonal maximum in upwelling favorable winds off northern California (Thomas and Strub, 2001). Off Oregon (ca. $\left.43^{\circ} \mathrm{N}\right)$, strong upwelling and highest Chl occurred in July. In late fall, low $\mathrm{Chl}$ again characterized the entire region. Comparison of CZCS results with SeaWiFS confirmed the seasonal patterns discussed above (Thomas et al., 2001a).

\section{Differences of the Seasonal Cycle} Between the two Hemispheres Owing to poor CZCS coverage of the Southern Ocean and the short (ninemonth) OCTS mission, SeaWiFS imagery was the first comprehensive ocean color image data set for quantifying seasonal cycles throughout the entire Southern Ocean. Results from the first year of SeaWiFS observation (October 1997 through September 1998) showed important features of the Southern Ocean, defined broadly as waters extending north from the Antarctic continent to $30^{\circ} \mathrm{S}$ (Moore and Abbott, 2000). Seasonal composite imagery confirmed that 

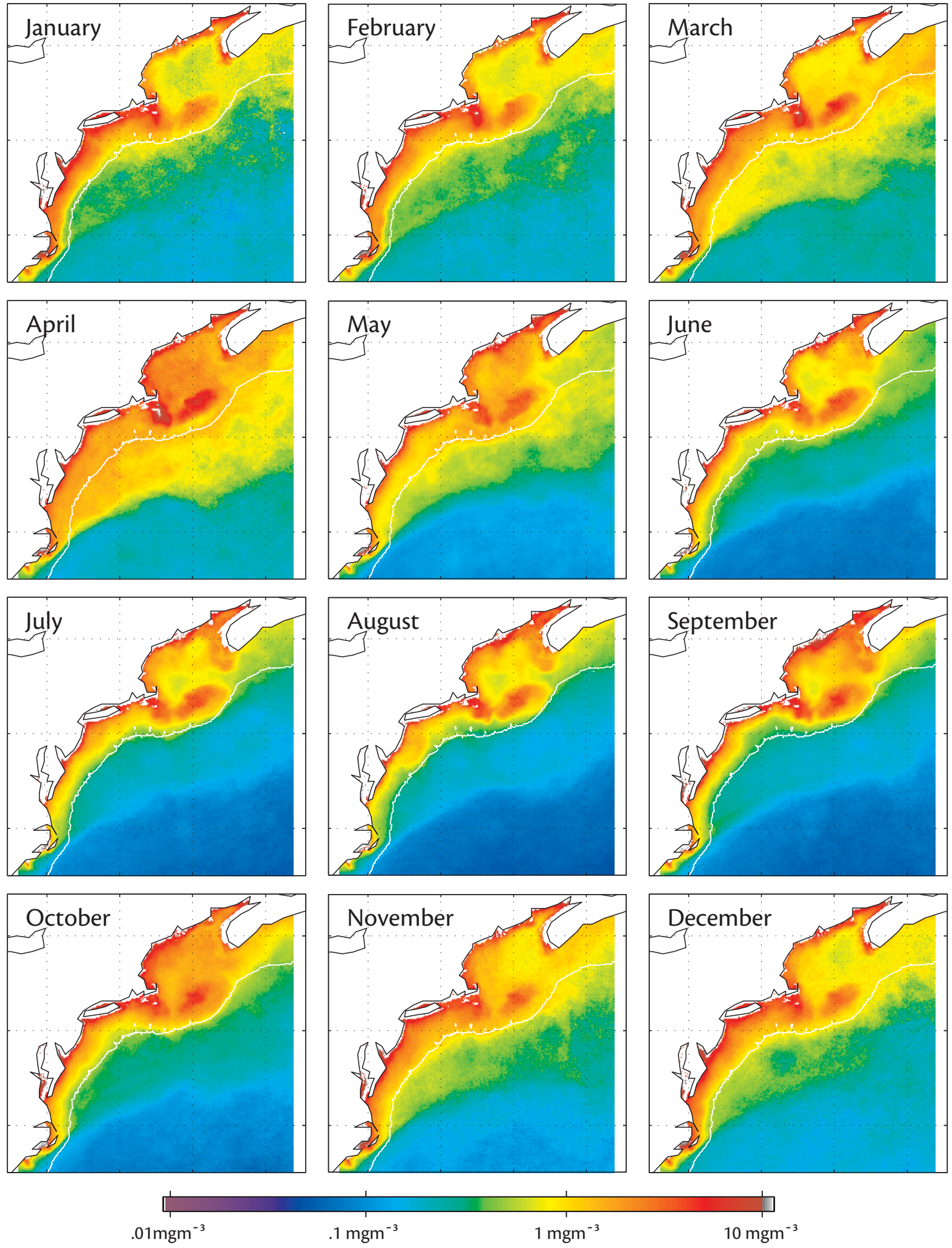

$.1 \mathrm{mgm}^{-3}$

$1 \mathrm{mgm}^{-3}$

$10 \mathrm{mgm}^{-3}$

Figure 4. SeaWiFS seven-year monthly mean composite images for ocean-margin waters off the northeast coast of the United States, including the Mid-Atlantic Bight (MAB) and Gulf of Maine (GOM). Note high Chl in comparatively shallow coastal waters in winter months (e.g., January to March); high April concentrations (spring bloom) in the GOM and in deeper waters of the MAB; and seasonally low concentrations during summer (July to August) in the deeper waters of the MAB. The white line in each image is the 500-m isobath. 
Chl was generally low in high-nutrient waters throughout this large region, although there were specific areas where Chl exceed $1.0 \mathrm{mg} \mathrm{m}^{-3}$ during growth seasons (spring and summer) (Moore and Abbott, 2000). These specific areas included shelf waters off the east coast of South America, as well as shelf waters off Africa, Australia, and New Zealand. Phytoplankton blooms were also observed in SeaWiFS imagery in parts of the Ross and Weddell Seas following seasonal ice retreat. In contrast to the North Atlantic, where seasonally high SeaWiFS Chl tends to be associated with broad latitude bands (Campbell and Aarup, 1992), SeaWiFS Chl in open waters of the Southern Ocean do not show large seasonal changes (iron limitation limits production in the Southern Ocean throughout the year, whereas seasonal changes in stratification are important in the North Atlantic). High Chl is located in comparatively narrow bands associated with the major Southern Ocean frontal systems (i.e., Southern Antarctic Circumpolar Current; Antarctic Polar, Subantarctic, South Subtropical, and the North Subtropical fronts) (Moore and Abbott, 2000).

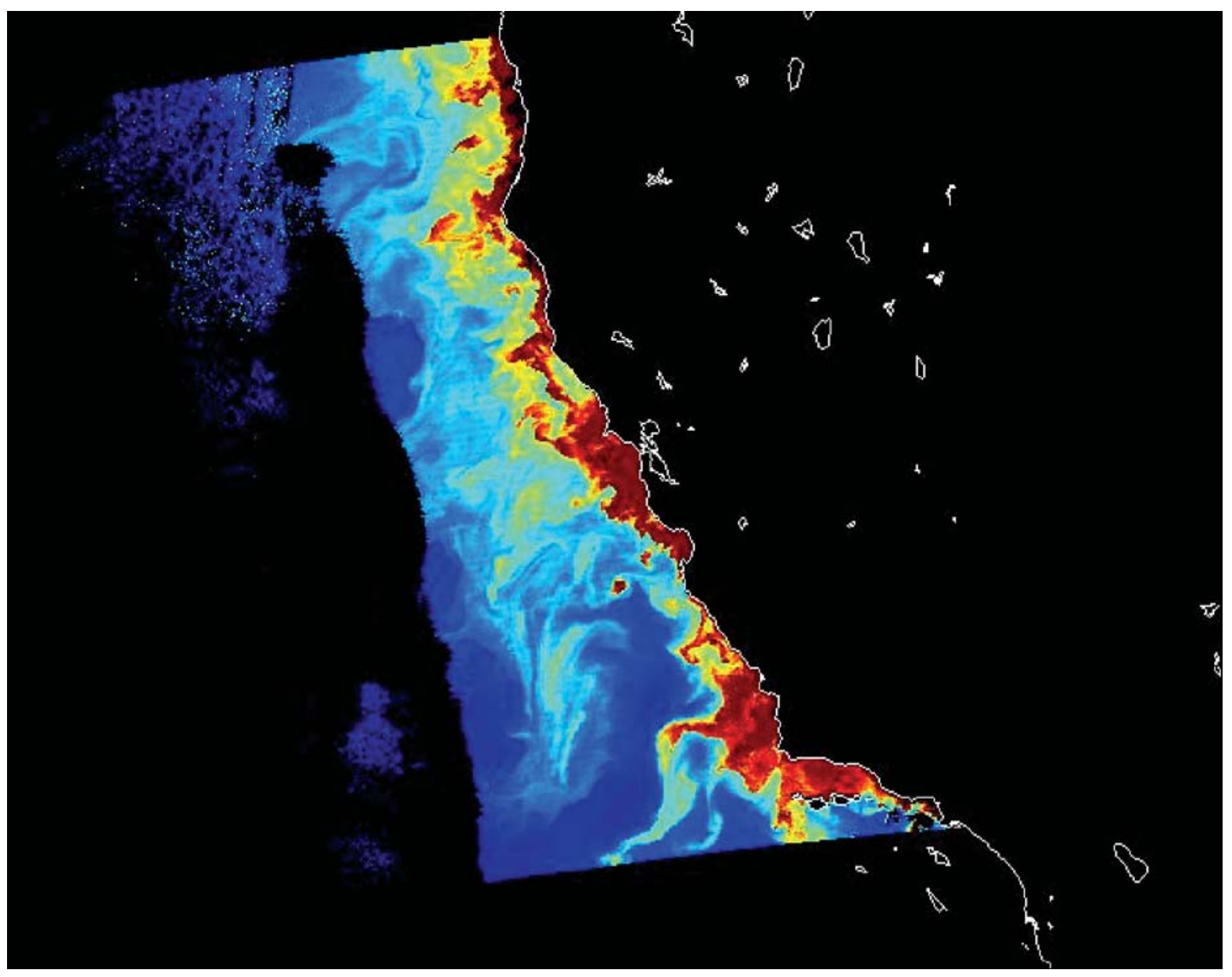

Figure 5. MODIS-Aqua Chl image from 30 August, 2005, showing mesoscale features in California coastal waters from about $33^{\circ}$ to $42^{\circ} \mathrm{N}$, including plumes of $\mathrm{Chl}$-rich upwelled waters extending many hundreds of kilometers offshore. The large plume in the lower right is off Point Conception just north of the Los Angeles basin. In the middle of the image is an area of Chl-rich upwelled waters centered off San Francisco Bay. Color coding similar to Figure 4. The Ocean Physics and Ecology Laboratory at Oregon State University produced this image in collaboration with NASA. 


\section{EL NIÑO-SOUTHERN OSCILLATION (ENSO)}

Changes in oceanographic conditions associated with ENSO have long been recognized as having dramatic biological impacts, particularly in the Equatorial Pacific (e.g., Barber and Chavez, 1983). Owing to anomalously low nutrient concentrations during El Niño, primary production is dramatically reduced causing severe consequences to higher trophic levels of the food web, including substantial reductions to the numbers of plankton-feeding fishes such as sardines and anchovies. CZCS imagery was available for the 1982-1983 El Niño; SeaWiFS imagery became available in fall
1997, and thus caught most of the large 1997-1998 ENSO cycle and the lesser 2002-2003 event. Analyses of image series provided detailed and quantitative observations on the dramatic regional impacts of the 1982-1983 and 19971998 El Niño and La Niña, as well as the progression of the effects throughout the Pacific basin. Satellite ocean color imagery provided the first direct observations of the basin-scale impact of ENSO on Chl distributions and how its effects propagate from the Equatorial Pacific along the eastern margin of the Pacific. In addition, the imagery showed the effects of ENSO on Chl distributions in other parts of the global ocean.
Propagation of ENSO Effects in the Pacific

The 1997-1998 ENSO cycle, including both the El Niño and La Niña phases, had dramatic effects in ocean color imagery (Figure 6). For example, note that 1998 (strong La Niña) was the year of maximum chlorophyll in many areas of the Pacific Ocean, particularly along the equator, whereas this was not the case in the Atlantic Ocean. Owing to changes from downwelling- to upwelling-favorable wind patterns during El Niño, Chl was highest in the Indian Ocean west of Indonesia during 1997 (strong El Niño). During the three-year period beginning in January 1998 (i.e., at the peak of the

Year of Maximum SeaWiFS Chl (Sept 1997 - Dec 2004)

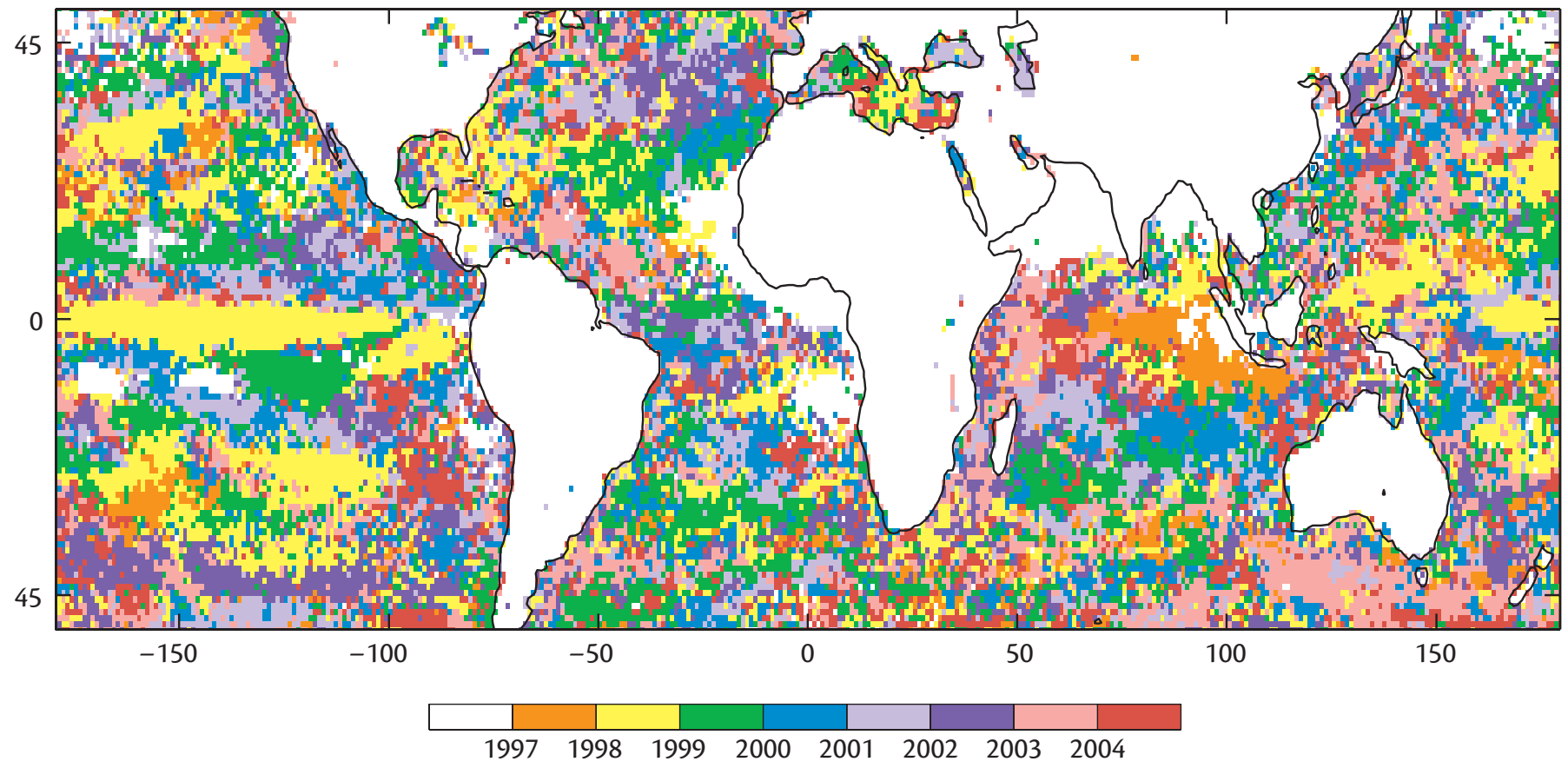

Figure 6. Image based on SeaWiFS global Chl images from September 1997 to December 2004 and from $50^{\circ} \mathrm{N}$ to $50^{\circ} \mathrm{S}$ showing the year in which the maximum Chl concentration was achieved in each pixel. Note the large number of pixels, particularly in the tropics and subtropics, in which the maximum occurred during the strong ENSO (El Niño and La Niña) of 1997-1998. 
El Niño phase), global monthly SeaWiFS imagery showed that interannual variability accounted for more than half of the total variability in the Pacific Equatorial region between $20^{\circ} \mathrm{N}$ and $20^{\circ} \mathrm{S}$, as well as in the California Current and Peru-Chile upwelling regions (Dandonneau et al., 2004).

Sea surface temperature (SST) and SeaWiFS-Chl imagery were used to study the ENSO cycle off Chile (Thomas et al., 2001b) and off the northwest U.S. coast between $46^{\circ} \mathrm{N}$ and $50^{\circ} \mathrm{N}$ (Sackmann et al., 2004). Previous CZCS studies of the California Current region did not observe much of an impact of the 19821983 El Niño north of Cape Blanco (Oregon coast, ca. $43^{\circ} \mathrm{N}$ latitude) (Thomas and Strub, 2001). In contrast, SeaWiFSChl and SST imagery of the 1997-1998 El Niño showed anomalously warm SST and reduced Chl, particularly in offshore waters, well into 1998 as far north as off Vancouver Island (ca. $48^{\circ} \mathrm{N}$ to $49^{\circ} \mathrm{N}$ ) (Sackmann et al., 2004).
SLH records. South of $20^{\circ} \mathrm{N}$ (off Costa Rica and Mexico), low Chl anomalies were apparent in 1982, but did not occur at sites north of $20^{\circ} \mathrm{N}$ until 1983 . This delay in low-Chl anomalies at the northern stations was surprising to the investigator, because the SST and SLH anomalies indicative of El Niño were evident at all sites beginning in mid-1982 (Lluch-Cota, 2002). One possible explanation is that the anomalies were not resolved in the California Current imagery during the low-Chl winter season of 1982-1983 and only became apparent in the imagery as low-Chl anomalies during the 1983 spring-summer upwelling season-the season when $\mathrm{Chl}$ is generally highest of the year. Thomas et al. (1994) compared CZCS-Chl image time series for the California Current System from about $20^{\circ} \mathrm{N}-$ $50^{\circ} \mathrm{N}$ and for the Peru Current system from about $5-50^{\circ} \mathrm{S}$. For both systems, El Niño resulted in low-Chl anomalies ca. $100 \mathrm{~km}$ from the coast, whereas waters near the coast were unaffected. For the

\section{Satellite ocean color imagery provided the}

\section{first direct observations of the basin-scale impact of ENSO on Chl distributions...}

For 1980-1986, Lluch-Cota (2002) compared CZCS-Chl time series with SST and SLH (sea level height) time series from selected locations along the western Pacific margin from ca. $38^{\circ} \mathrm{N}$ (off San Francisco, California) to $9^{\circ} \mathrm{N}$ (off Costa Rica). Not surprisingly, the 1982-1983 ENSO was the largest source of interannual variability in Chl, SST, and
Peru Current, negative Chl anomalies were not observed poleward of $20^{\circ} \mathrm{S}$ (off the coast of Chile), whereas the anomalies were observed about 20 degrees farther poleward in the California Current. The investigators were careful to point out that their conclusions were tentative given the poor CZCS image coverage of the Peru Current System compared to imagery available for the California Current (Thomas et al., 1994).

EOF (empirical orthogonal function) analyses of a two-year time series of SeaWiFS Chl imagery and SSH anomalies derived from TOPEX altimeter data provided considerable insight into the dynamics affecting observed Chl variability in the Equatorial Pacific during the ENSO cycle that commenced in 1997 (Wilson and Adamec, 2001). The dominant response revealed by these analyses was a symmetric off-equatorial Chl increases during the La Niña phase that occurred between $2^{\circ}$ and $18^{\circ}(\mathrm{N}$ and S) from the eastern Pacific to the date line. The Chl pattern was closely related to $\mathrm{SSH}$, indicating the $\mathrm{Chl}$ increase was caused by an increase in surface nutrients related to a shoaling thermocline. This response had not been previously reported and illustrates the observing capabilities of multiple ocean remote sensors to study ocean variability. Other important EOF modes in the Wilson and Adamec study included the expected equatorial decrease in Chl during $\mathrm{El}$ Niño, followed by a significant increase during La Niña such as reported by others (e.g., Chavez et al., 1999; McClain et al., 2002) (see Figure 7). Their results also showed a positive $\mathrm{Chl}$ anomaly between the equator and $15^{\circ} \mathrm{N}$ in the western Pacific (warm pool) associated with a shoaling thermocline during El Niño.

\section{ENSO Effects in Basins Other} than the Pacific

Although one expects a strong ENSO signature in the Equatorial Pacific and the ocean margin waters of the eastern Pacific, ENSO effects are also observed in other regions of the global ocean (e.g., 
REOF 3: $8.8 \%$

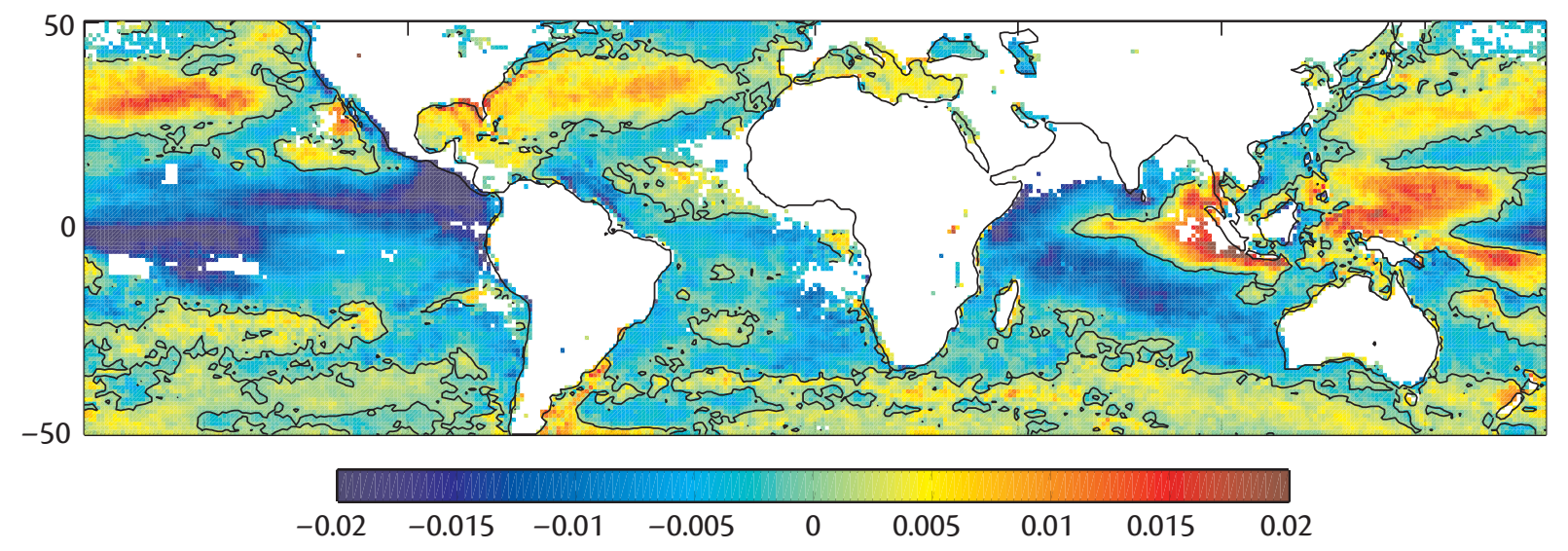

Amplitudes for Mode 3

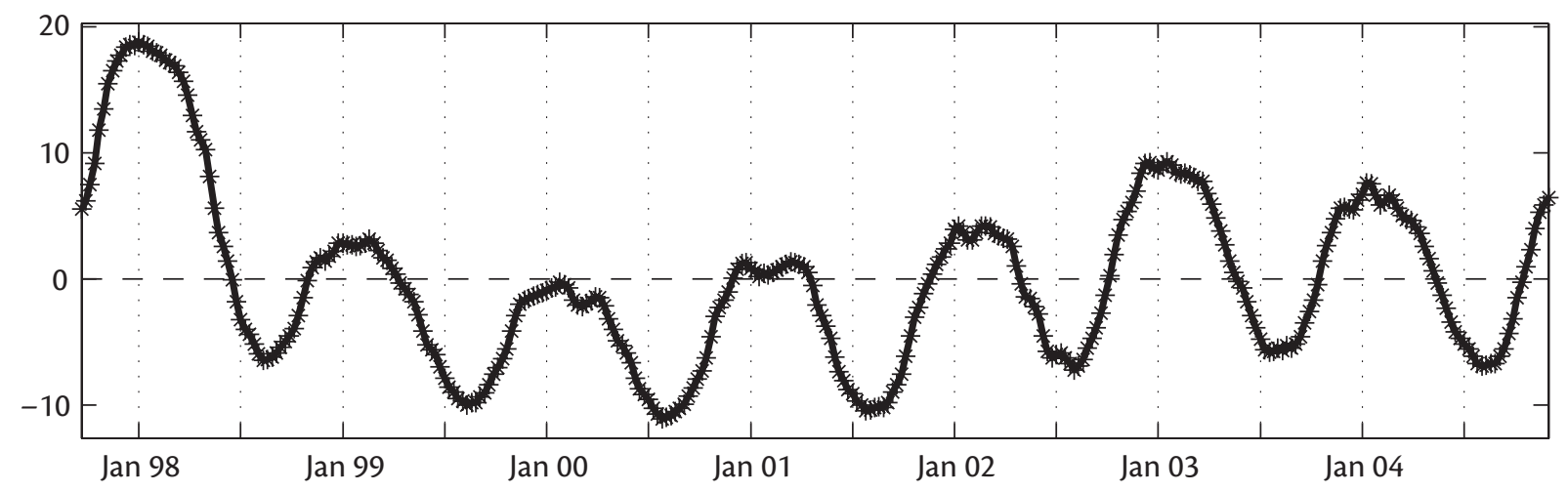

Figure 7. Mode 3 (ENSO effects) from analyses as described for Figure 3. Note features discussed in the text near the peak of the El Niño (ca. January 1998), including low Chl anomaly centered on the equatorial Pacific and the high Chl anomalies in the Indian Ocean west of Indonesia, Gulf of Mexico and North Atlantic, and in the western Pacific warm pool.

Behrenfeld et al., 2001; Yoder and Kennelly, 2003; Dandonneau et al., 2004). For example, Figure 7 shows a SeaWiFSChl ENSO mode derived from EOF analyses of multi-year global image time series (ESNO effects are most noticeable in EOF Mode 3 [i.e., Figure 7], whereas seasonal effects dominate Mode 1 [shown in Figure 3]). Note that high Chl anomalies occur in the Indian Ocean off Indonesia owing to strong upwelling during El Niño in response to upwelling- favorable shifts in the monsoon winds. Positive $\mathrm{Chl}$ anomalies are also present in the Gulf of Mexico and subtropical North Atlantic in January 1998, possibly owing to anomalously high rainfall (and river runoff ) in the southeast United States during El Niño (Yoder and Kennelly, 2003).

The effects of the 1997-1998 ENSO were also projected into the tropical and South Atlantic affecting Chl along the equator, the upwelling system off northwest Africa (Signorini et al., 1999), and the Benguela upwelling system (Weeks and Shillington, 1994). Comparing SeaWiFS imagery from 1997 and 1998 with CZCS imagery from a decade earlier showed that Chl in December 1997 along the equator east of $30^{\circ} \mathrm{W}$ were $<0.3 \mathrm{mg} \mathrm{m}^{-3}$ compared to $>1.0 \mathrm{mg} \mathrm{m}^{-3}$ for the same location and month in composite CZCS images (Monger et al., 1997; Signorini et al., 1999). The extent of the ocean area af- 
fected by the northwest African upwell-

ing system was also substantially reduced

from November through December 1997

compared to the non-ENSO years of

CZCS coverage (Signorini et al., 1999).

\section{OTHER INTERANNUAL}

\section{VARIATIONS}

ENSO is a major source of interannual variability, but there are other strong interannual signals evident in ocean color imagery. Identifying sources of interannual variability and quantifying their effects are important research goals - understanding variability at these comparatively long periods is crucial if we are to separate natural cycles from potential impacts of human activities. At present, we have well-calibrated, continuous ocean color observations extending for almost a decade. Analyses of this time series, supported by in situ observations, are leading to new understanding and better quantification of biological and biogeochemical interannual vari-
During the first four years of SeaWiFS imagery (1997-2001), Thomas et al. $(2003,2004)$ found a relation between Chl variability in the Gulf of Maine and the NAO index. Of the four years studied, Chl was lowest in the Gulf of Maine during 1998, including weak spring and fall blooms during that year, coinciding with a shift to the negative state of the NAO index. Wind patterns in 1998 were similar as for other years, but changes in hydrographic conditions in the Gulf of Maine are related to changes from positive to negative NAO index values (Thomas et al., 2003). Specifically, Labrador Subarctic Slope Water penetrates into the deeper basins of the Gulf of Maine during years when the index is negative. This water mass is colder and contains lower nutrient concentrations than the water mass it displaces. Decreased Chl in 1998 was attributed to weaker spring stratification in the upper water column owing to the cold subsurface water mass, as

\section{...understanding variability at these}

comparatively long periods is crucial if we are to separate natural cycles from potential impacts of human activities.

ability. For the first time, the impact of the oceanographic conditions associated with the North Atlantic Oscillation (NAO) index on a variable related to biological and biogeochemical processes (i.e., Chl) can be observed on the scale of an ocean basin. well as to lower nutrient concentrations to support phytoplankton growth (Thomas et al., 2003). During the same four-year period (1997-2001), Chl during the spring growth period in 1998 was lower in the slope sea of the MAB than in the other three years (Schollaert et al.,
2004). The explanation for the low 1998 Chl also involved southward flow of Labrador waters into the region (Schollaert et al., 2004). The area of the slope sea is bounded to the north by topography (e.g., the 2500-m isobath) and to the south by the north wall of the Gulf Stream (e.g., see Figure 4). The mean position of the north wall changes at approximately month-to-year time scales by up to $200 \mathrm{~km}$, resulting in interannual changes to the area of the Slope Sea (Schollaert et al., 2004). During years when high amounts of Labrador Sea water flow southward into the Slope Sea, the Gulf Stream is pushed south expanding the area of the Slope Sea. When the flow of Labrador Sea water is relatively low, the Gulf Stream wall moves farther north thereby contracting the area of the Slope Sea. However, Chl is higher when the area is smaller, because nutrient flux (from subsurface Gulf Stream waters) is the same, but is into a smaller area (Schollaert et al., 2004). The result is that the area-integrated chlorophyll (Chl X area) in surface waters of the Slope Sea is comparatively constant. In other words, small Slope Sea area during low flow of Labrador Sea water multiplied by higher Chl tends to equal the situation of comparatively large Slope Sea area multiplied by lower Chl. Thus, interannual variability is observed in Chl in the Slope Sea, but is not reflected in area-integrated chlorophyll (Schollaert et al., 2004).

Interannual variability in spring $\mathrm{Chl}$ in open-ocean waters of the subtropical North Atlantic is also related to changes in oceanographic and meteorological conditions indexed by the NAO (Dutkiewicz et al., 2001; Follows and Dutkiewicz, 2002). Winter winds are stronger, 
mixing is deeper, and nutrient flux is higher in the subtropical North Atlantic during negative states of the NAO. Owing to the greater nutrient flux, $\mathrm{Chl}$ is higher in the subtropics when NAO is in the negative state than when in the positive state (Follows and Dutkiewicz, 2002). Yoder and Kennelly (2003) showed that $\mathrm{Chl}$ in subpolar waters of the North Atlantic was somewhat higher during years of negative NAO index, but also concluded that NAO-related effects observed in SeaWiFS imagery did not have the impact, even in the North Atlantic, of the strong ENSO of 1997-1998.

\section{MESOSCALE AND HIGH -}

\section{FREQUENCY VARIABILITY}

Mesoscale features (i.e., those associated with space scales of the order of $10-100 \mathrm{~km}$ ) are often difficult to study using only in situ sampling methods, as features evolve, advect, and dissipate quickly (days to weeks). Yet, mesoscale variability affects the structure and function of marine ecosystems as well as biogeochemical fluxes. Full-resolution imagery is rich with mesoscale features such as eddies, filaments, and other features. Open-ocean and coastal phenomena such as upwelling plumes (e.g., Figure 5), frontal eddies, ocean eddies, and planetary waves affect Chl variability at about ten- to hundred-kilometer spatial scales and days-to-weeks temporal scales. As discussed below, satellite SST and Chl observations provided new insights into the space-time variability caused by such phenomena by extending the scales of observation from those that were possible using only ship or mooring measurements and by contributing a two-dimen- sional view of their effects at the ocean surface. In addition, ocean color imagery provided the first observations of the effects of planetary waves on a biological distribution (Chl).

\section{Mesoscale Space-Time Variability} Close relations (coherence) between surface temperature and phytoplankton chlorophyll at spatial scales from approx- versus $\log$ wavenumber relation (in the range $10^{0}$ to $0.5 \times 10^{3} \mathrm{~km}$ ) showed that SST and Chl had similar spectral slopes at $10-100-\mathrm{km}$ scales, but had different slopes at the 1-10-km scale (Smith et al., 1988). Smith et al. (1988) interpreted the results to mean that biological processes were important at $1-10-\mathrm{km}$ scales (similar to conclusions based on in situ data), whereas both SST and Chl were imately millimeters to tens of kilometers was first documented by using Fourier analysis to analyze data collected with in situ sensors (e.g., Denman and Platt, 1975). Fourier analyses of data collected along ship transect lines were commonly plotted as $\log$ spectral density versus log wavenumber, and the slope of the relation used as the basis for interpretation. A common result was that the slopes of chlorophyll and SST were comparable and of a magnitude indicative of turbulent mixing over much of the wavenumber space. Similar methods were used to analyze satellite Chl and SST measurements, and the results expanded this analysis technique to larger scales and from one-dimensional transects to twodimensional fields. Using data extracted from CZCS-Chl and SST imagery of the California Current region off Point Conception $\left(\mathrm{ca} .35^{\circ} \mathrm{N}\right)$, results based on slope changes of the log spectral density behaving as passive scalars (i.e., mixing processes controlled the distributions) at larger scales. Merging satellite and in situ results generated a continuous and consistent spectral density versus wavenumber spectrum from ca. $10^{-3}$ to $10^{3} \mathrm{~km}$ (Smith et al., 1988).

Cross-spectrum analysis was used to study spatial patterns in two CZCS-Chl image time series (July 21 to August 8, 1980 and September 6-13, 1981) for the offshore region off Vancouver Island (ca. $50^{\circ} \mathrm{N}$, west coast of Canada) (Denman and Abbott, 1988). By examining the rate at which squared coherence changed with time (i.e., the rate at which the spatial pattern changed with time), the investigators showed that the rate of decorrelation depended on length scale as well as coastal versus offshore location. Patterns associated with the 12.5$25-\mathrm{km}$ scale in both offshore and coastal waters were not statistically different 
(90 percent confidence) within 1-2 days, and they were completely uncorrelated after 5-7 days. Larger features $(>50-\mathrm{km}$ scale) in offshore waters did not decorrelate as rapidly and were still coherent after one week (Denman and Abbott, ly fast to significantly modify Chl spatial patterns at the 1 to $>100-\mathrm{km}$ scale that are created by mixing and dispersion processes (Denman and Abbott, 1994).

Spatial scales were calculated in a oneyear time series of daily global SeaWiFS

\section{Quantifying long-term trends in global ocean ecosystems and biogeochemical cycles and understanding the causes of observed changes is an important goal of national and
international research programs.}

1988). The investigators also concluded that the rapid decorrelation observed in their study and other similar studies resulted in part from their Eulerian (fixed grid) analyses (i.e., translational and rotational feature movements contribute to decorrelation even though the feature structure per se may not change) (Denman and Abbott, 1988). A follow-on study of the California Current region off California compared pattern evolution in SST and CZCS-Chl imagery using cross-spectrum analysis (Denman and Abbott, 1994). The results showed no significant differences between spectral shapes nor rates of decorrelation for SST and Chl features. In two of three study areas, peak correlation between SST and Chl spectra occurred at zero lag. In the third study area, maximum coherence occurred when Chl lagged SST by 1-2 days, as would be expected in an upwelling region (Denman and Abbott, 1994). The results were consistent with modeling studies showing that phytoplankton growth rates are not sufficient-
Chl imagery ( 9 x $9 \mathrm{~km}$ pixel resolution) (Doney et al., 2003). The results showed dominant scales in the range $50-250 \mathrm{~km}$ that varied roughly in proportion to the Rossby deformation radius and were very similar to prior results of SSH anomalies (Doney et al., 2003). As for the SSH study, the Chl results support the hypothesis that the primary process driving the formation of mesoscale eddies is baroclinic instability of the density field (Doney et al., 2003). The investigators also showed a very high degree of unresolved variance in the imagery, which was either algorithm/sensor noise or caused by submesoscale processes (Doney et al., 2003; see Box 1).

\section{Planetary and Other Waves}

Two articles, published within two weeks of each other, provided the first evidence that Rossby waves affected Chl distributions in the global ocean (Cipollini et al., 2001; Uz et al., 2001). Both articles also showed that the features observed in both SSH and Chl imagery propagated at similar speeds, and both proposed that one explanation for the observations was that the waves were pumping nutrients into near-surface waters thereby stimulating phytoplankton growth. A subsequent study of Rossby waves and their effects on (apparent) Chl distributions challenged the nutrient pumping mechanism, at least in the tropics, and proposed an alternative explanation for the observations. Specifically, Dandonneau et al. (2003) concluded that the apparently high $\mathrm{Chl}$ anomalies were concentrated in Rossby-wave-induced convergence zones. Furthermore, they postulated that detrital material, not chlorophyll $a$-containing phytoplankton, had accumulated in the convergence zones and yielded a false Chl signal in the imagery (Dandonneau et al., 2003). Killworth (2004) challenged this interpretation by showing that particles do not converge in a plane planetary wave. In addition, in situ observations of the effects of Rossby waves at the Hawaii Ocean Time Series (HOT) site $\left(22^{\circ} 45^{\prime} \mathrm{N}\right.$, $158^{\circ} \mathrm{W}$ ) off Hawaii in the subtropical North Pacific supported the explanation of nutrient pumping as the cause of high Chl anomalies (Sakamoto et al., 2004). Finally, Killworth et al. (2004) re-analyzed the $\mathrm{Chl}$ and SSH data, compared the results with different numerical models of wave dynamics, and concluded that north-south advection of Chl against the background gradient could account for most of the observed Rossby wave effects in Chl imagery. However, the nutrient pumping mechanism could not be ruled out as the cause for some of the variability (Killworth et al., 2004). In summary, all agree that Rossby waves affect Chl (or apparent Chl) variability in near-surface waters, but there is disagreement as to 
how to best explain the observations.

Tropical instability and other wavelike motions also affect variability through their effects on upwelling and nutrient supply. Ryan et al. (2002) showed large, propagating, high-Chl features in the Equatorial Pacific, as the system shifted from El Niño to La Niña phase in 1998. During 1998, Legeckis et al. (2004) documented five episodes of elevated $\mathrm{Chl}$ in the Pacific around the Marquesas Islands $\left(140^{\circ} \mathrm{W}, 10^{\circ} \mathrm{S}\right)$ and attributed them to upwelling of iron-rich waters associated with westward-propagating tropical instability waves.

\section{LONG-TERM TRENDS}

Quantifying long-term trends in global ocean ecosystems and biogeochemical cycles and understanding the causes of observed changes is an important goal of national and international research programs. Time series of satellite measurements of water-leaving radiance and derived products (e.g., Chl) are one are too short to fully answer this question, but recent results demonstrate that changes have occurred.

In a four-year SeaWiFS time series (1998-2001), Dandonneau et al. (2004) showed linear Chl increases in such areas as the Costa Rica Dome region, a plume of the Amazon River, as well as in the upwelling regions off Somalia and in the tropical eastern boundary systems (e.g., California and Benguela). Decreases were greatest in some other coastal areas, particularly off the U.S. East Coast. Increases in the Pacific were attributed to the recovery from the 1997-1998 El Niño, but explanations for changes in the other regions were not clear. Gregg et al. (2005) analyzed a six-year SeaWiFS time series with somewhat similar results to those of Dandonneau et al. (2004). Their analyses of the six-year series showed that regions of increasing Chl included the eastern Pacific and Somalian coast, and increases over that period were also observed on the Patagonian shelf and Bering Sea.

\section{Significant enhancements and improvements}

will continue into the future as new sensors and new processing techniques come on line.

tool for monitoring long-period changes in the ocean, and recent studies show changes during the past decade or more. Are these long-term trends caused by changes to Earth's climate, or are they responses to natural ocean cycles that are not yet fully understood? Time series of satellite ocean color measurements
Decreases were noted in four of the five ocean gyres and coincided with significant increases in SST during at least one season of the year (Gregg et al., 2005). Gregg et al. (2005) hypothesized that Chl increases in coastal areas were related to a warming Earth, which enhances coastal upwelling. Antoine et al. (2005) repro- cessed CZCS and SeaWiFS imagery using a consistent approach to examine global Chl patterns between the 1980s and 2000s. Their most important finding was that Chl has increased globally between the two decades by 22 percent, primarily as a result of increases in subtropical (intertropical) areas. Changes were not as dramatic at higher latitudes, and $\mathrm{Chl}$ in the oligotrophic gyres declined.

\section{CONCLUSIONS}

The quick answer to the question posed in the title of this article is that ocean color imagery provides a new window on upper-ocean variability related to biological and biogeochemical processes, which has had a profound effect on the fields of chemical and biological oceanography in particular. We now have a much improved quantitative understanding of upper-ocean seasonal cycles in the global ocean and how seasonal cycles differ among ocean basins and with latitude. Image time series also gave us our first global view of the year-to-year stability of the key features of seasonal cycles on the scale of ocean basins both in terms of the magnitude of phytoplankton biomass (Chl) peaks and troughs, as well as their timing. Differences between the Southern Ocean and the higher latitudes of the Northern Hemisphere are now established. From SeaWiFS imagery, we now know that the major frontal systems are the sites for relatively high $\mathrm{Chl}$ in open waters of the Southern Ocean. The impact of major ENSO cycles (e.g., 1982-1983 and 1997-1998) on phytoplankton biomass variability has been directly observed; not just in the equatorial Pacific but throughout the global ocean. Important linkages between patterns ob- 
As for any measurement system, one has to learn how to separate valid from invalid measurements, identify artifacts, and recognize contaminated signals, loss of calibration, loss of stability, sensor degradation, and other measurement challenges. This task can be particularly difficult for satellite systems because they operate in a harsh environment and the instruments are never visited nor recovered. In the case of ocean color measurements, the atmosphere contributes most of the signal observed by the sensor; some atmospheric components are highly variable and not well constrained in image processing. As a result, satellite ocean color measurements are particularly vulnerable to artifacts and biases that can adversely affect the accuracy of the $\mathrm{Chl}$ patterns observed in the imagery and its interpretation. Thus, some of the observed temporal or spatial variability calculated from satellite images may not be caused by ocean processes. An example is illustrated below.

Uz and Yoder (2004) showed that temporal variability within a thirty-day window and spatial variability in $2 \times 2$ degree neighborhoods observed in a three-year time series of daily SeaWiFS Chl images was inversely related to mean values calculated over the same temporal and spatial domains. In other words, some parts of the western Pacific having among the lowest mean $\mathrm{Chl}$ in the global ocean also had the highest standard deviation (of log-transformed data) in daily SeaWiFS images. This was an intriguing result, which was difficult to explain from an ocean process point of view, although a previous study sug-

Standard deviation of log-transformed SeaWiFS chl (2003)

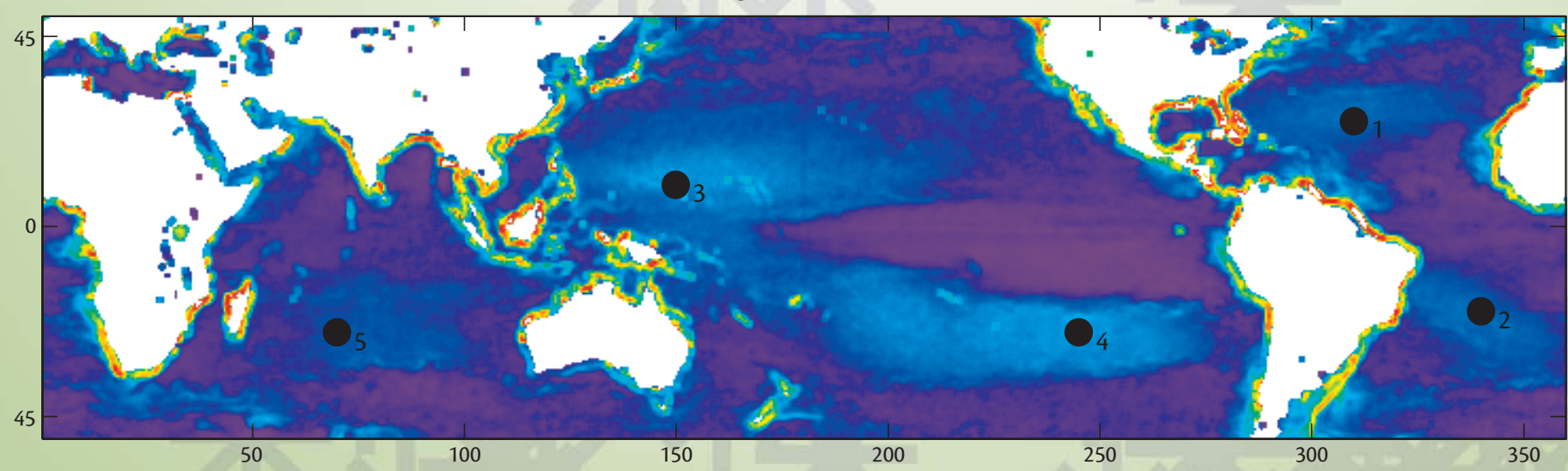

Standard deviation of log-transformed MODIS chl (2003)

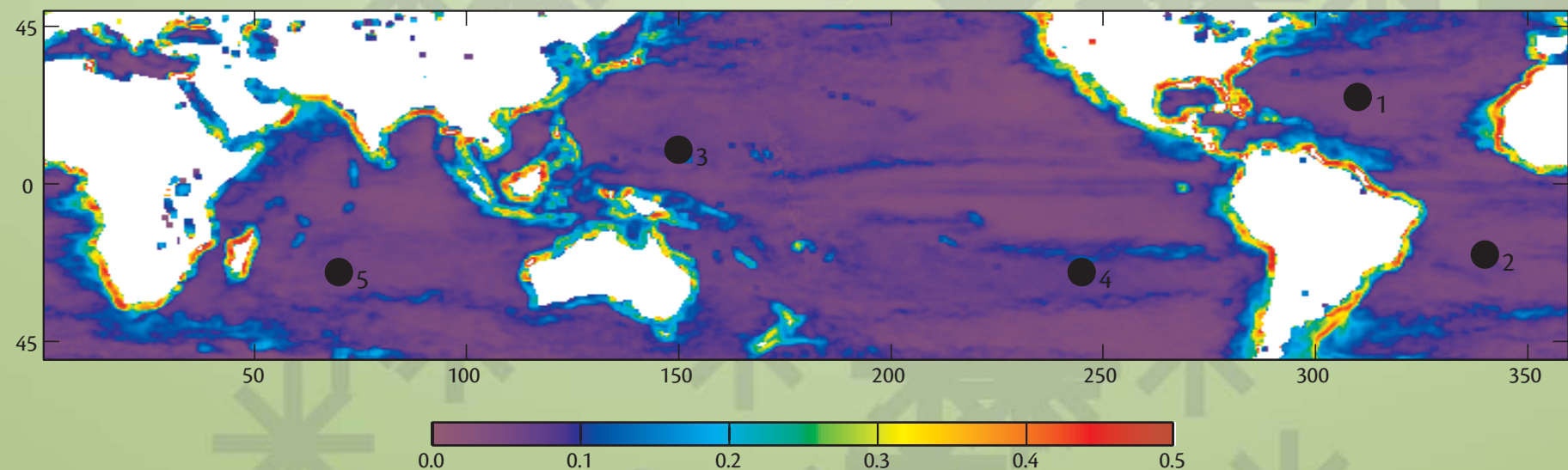

Images showing the ensemble average standard deviation (std) of $\log \mathrm{Chl}$ calculated spatially within $2 \times 2$-degree neighborhoods for all daily, $9 \times 9$-km resolution SeaWiFS and MODIS images from 2003. The spatial patterns associated with high std in open-ocean waters (e.g., South Pacific) in the SeaWiFS image are similar to results previously reported (Uz and Yoder, 2004) but are absent or much reduced in the MODIS image. Comparing the SeaWiFS results from Figure 1 and the above suggests an unusual inverse relation between mean values and std (log units). The five black dots identify locations for the time series shown in the figure to the right. 
gested that such phenomena might be caused by inaccurate atmospheric correction or other artifacts (Doney et al., 2003). The left figure shows Chl standard deviation (std) images from MODIS (on Aqua) and SeaWiFS calculated per Uz and Yoder (2004), but for daily images from (2003). The SeaWiFS image shows the aforementioned mean versus standard deviation pattern (compare the left figure with Figure 1), but it is not observed in the MODIS image. As discussed earlier, the standard $\mathrm{Chl}$ algorithm is based on a ratio of water-leaving radiance of a blue band (e.g., $443 \mathrm{~nm}$ ) and a green band (e.g., $555 \mathrm{~nm}$ ). In low-Chl open-ocean waters, water-leaving radiance is quite high at $443 \mathrm{~nm}$, but considerably lower at $555 \mathrm{~nm}$. Sensor or algorithm noise at $555 \mathrm{~nm}$ potentially has a larger impact on $\mathrm{Chl}$ measurement precision than the same level of noise at $443 \mathrm{~nm}$. The right figure shows a time series of the coefficient of variation ( $C V=s t d / m e a n)$ for the water-leaving radiance at $555 \mathrm{~nm}$ for SeaWiFS and MODIS-Aqua for the same images used for the Chl standard deviation images (left figure) and for the locations indicated in that figure. The right figure shows that the $\mathrm{CV}$ is considerably lower and less variable for MODIS than for SeaWiFS (i.e., SeaWiFS is a noisier instrument system over the open ocean than is MODIS). Thus, the apparent inverse relation between mean $\mathrm{Chl}$ and its standard deviation observed in SeaWiFS imagery (but not MODIS imagery) is likely an artifact caused by comparatively high noise associated with SeaWiFS measurements at the band centered at $555 \mathrm{~nm}$ and the subsequent impact on the band-ratio $\mathrm{Chl}$ algorithm.
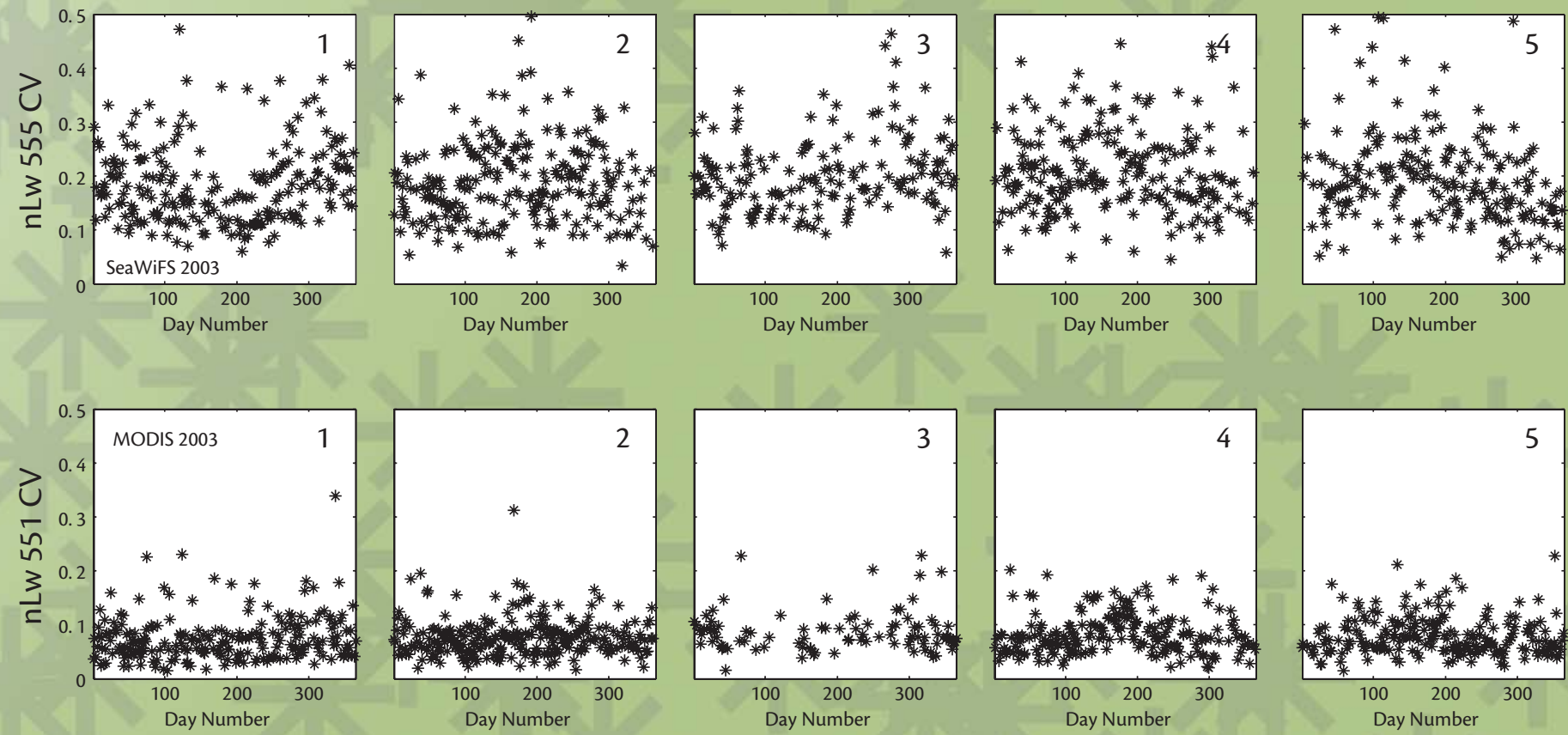

Water-leaving radiance in the green band (centered at 551 or $555 \mathrm{~nm}$ ) at the locations illustrated in the figure to the left and for the same one-year time series. Note that variability (CV = coefficient of variability) of green-band radiance is much lower in MODIS than in SeaWiFS imagery. This result suggests that the apparent inverse relation between mean values and standard deviation (std) evident in the SeaWiFS imagery is likely an artifact related to high sensor or algorithm noise. 
served in ocean color imagery and ocean dynamics associated with ENSO (e.g., as evidenced by SSH anomalies) are now established and help explain biological variability. Other climate signals, such as those correlated with the NAO index, are also observed in the imagery and their characteristics and regional- to basinscale impact are now better quantified. We also have a much better quantitative understanding of mesoscale variability and for the first time, observed the global effects of planetary waves on a biological variable. Finally, we have our first direct observations of decadal changes in $\mathrm{Chl}$ for the global ocean.

Image processing has advanced considerably since the launch of CZCS in 1978, but the imagery still retains some artifacts that can confound applications. Significant enhancements and improvements will continue into the future as new sensors and new processing techniques come on line. These developments will lead to better quantitative analyses of phytoplankton biomass patterns, as well new bio-optical parameters that can be derived and analyzed from the ocean-color measurements. As time series grow in length, long-term trends or permanent changes in the upper ocean will be revealed, and ultimately, this capability might be the most important future application for the imagery.

\section{ACKNOWLEDGEMENTS}

We acknowledge the technical assistance and many scientific discussions with S. Schollaert and M. Uz, who contributed to this article, as well as the helpful comments from C. Brown and K. Moore. We thank the Ocean Physics and Ecology Laboratory at Oregon State University for the image in Figure 5 and OrbImage and NASA's SeaWiFS Project for the SeaWiFS data. Funding was provided by NASA Headquarters grant NAG5-10555 and by the National Oceanographic Partnership Program (PARADIGM project). ש

\section{REFERENCES}

Abbott, M.R., and P.M. Zion. 1987. Spatial and temporal variability of phytoplankton pigment off northern California during coastal ocean dynamics experiment 1. Journal of Geophysical Research 92:1,745-1,755.

Antoine, D., A. Morel, H.R. Gordon, V.F. Banzon, and R.H. Evans. 2005. Bridging ocean color observations of the 1980s and 2000s in search of long-term trends. Journal of Geophysical Research 110:C06009, doi:10.1029/2004JC002620.

Barber, R.T., and F.P. Chavez. 1983. Biological consequences of El Niño. Science 222:1,203-1,210.

Barnard, A.H., P.M. Stegmann, and J.A. Yoder. 1997. Seasonal surface ocean variability in the South Atlantic Bight derived from CZCS and AVHRR imagery. Continental Shelf Research 17:1,181-1,206.

Behrenfeld, M.J., J.T. Randerson, C.R. McClain, G.C. Feldman, S.O. Los, C.J. Tucker, P.G. Falkowski, C.B. Field, R. Frouin, W.E. Esaias, D.D. Kolber, and N.H. Pollack. 2001. Biospheric primary production during an ENSO transition. Science 291:2,594-2,597.

Campbell, J.W., and T. Aarup. 1992. New production in the North Atlantic derived from seasonal patterns of surface chlorophyll. Deep-Sea Research 39:1,669-1,694.

Chavez, F.P., P.G. Strutton, G.E. Friederich, R.A. Feely, G.C. Feldman, D.G. Foley, and M.J. McPhaden. 1999. Biological and chemical response of the Equatorial Pacific Ocean to the 1997-1998 El Niño. Science 286:2,126-2,131.

Cipollini, P., D. Cromwell, P.G. Challenor and S. Raffaglio. 2001. Rossby waves detected in global ocean color data. Geophysical Research Letters 28:323-326.

Cushing, D.H. 1959. The seasonal variation in oceanic production as a problem in population dynamics. Journal du Conseil International pour l'Exploration de la Mer 24:455-464.

Dandonneau, Y., A. Vega, H. Loisel, Y. du Penhoat, and C. Menkes. 2003. Oceanic Rossby waves acting as a «Hay Rake» for ecosystem floating by-products. Science 302:1,548-1,551.

Dandonneau, Y., P.Y. Deschamp, J-M. Nicolas, H. Loisel, J. Blancho, Y. Montel, F. Thieuleux, and G. Bécu. 2004. Seasonal and interannual variability of ocean color and composition of phytoplankton communities in the North Atlantic, equatorial Pacific and South Pacific. Deep-Sea Research II - Topical Studies in Oceanography 51:303-318.

Denman, K.L., and M.R. Abbott. 1988. Time evolution of surface chlorophyll patterns from crossspectrum analysis of satellite color. Journal of Geophysical Research 93:6,789-6,998.

Denman, K.L. and M.R. Abbott. 1994. Time scales of pattern evolution from cross-spectrum analysis of advanced very high resolution radiometer and coastal zone color scanner imagery. Journal of Geophysical Research 99:7,433-7,442.

Denman, K.L., and T. Platt. 1975. Coherences in the horizontal distributions of phytoplankton and temperature in the upper ocean. Memoires Societe Royale des Sciences de Liege 7:19-30.

Doney, S.C., D.M. Glover, S.J. McCue, and M. Fuentes. 2003. Mesoscale variability of Seaviewing Wide Field-of-view Sensor (SeaWiFS) satellite ocean color: Global patterns and spatial scales. Journal of Geophysical Research 108(C2):3024, doi:10.1029/2001JC000843.

Dutkiewicz, S., M. Follows, J. Marshall, and W.W. Gregg. 2001. Interannual variability of phytoplankton abundances in the North Atlantic. Deep-Sea Research II 48:2,323-2,344.

Esaias, W.E., G.C. Feldman, C.R. McClain, and J.A. Elrod. 1986. Monthly satellite-derived phytoplankton pigment distribution for the North Atlantic Ocean Basin. EOS Transactions of the American Geophysical Union 67:835-837.

Feldman, G., N. Kuring, C. Ng, W. Esaias, C. McClain, J. Elrod, N. Maynard, D. Endres, R. Evans, J. Brown, S. Walsh, M. Carle, and G. Podesta. 1989. Ocean color: Availability of the global data set. EOS Transactions of the American Geophysical Union - The Oceanography Report 70(23):634-635, 640-641.

Follows, M., and S. Dutkiewicz. 2002. Meteorological modulation of the North Atlantic spring bloom. Deep-Sea Research II 49:321-344.

Fuentes-Yaco, C., A.F. Vezina, P. Larouche, C. Vigneau, M. Gosselin and M. Levasseur. 1997a. Phytoplankton pigment in the Gulf of St. Lawrence, Canada, as determined by the Coastal Zone Color Scanner-Part I: Spatio-temporal variability. Continental Shelf Research 17:1,4211,429 .

Gregg, W.W., N.W. Casey, and C.R. McClain. 2005. Recent trends in global ocean chlorophyll. Geophysical Research Letters 32:L03606, doi:10.1029/2004GL021808.

Killworth, P.D. 2004. Comment on "Oceanic Rossby waves acting as a 'Hay Rake' for ecosystem floating by-products." Science 304:390c, doi10.1126/science.

Killworth, P.D., P. Cipollini, B.M. Uz, and J.R. Blundell. 2004. Physical and biological mechanisms for planetary waves observed in satellite-derived chlorophyll. Journal of Geophysical 
Research 109, doi:10.1029/2003JC001768.

Legeckis, R., C.W. Brown, F. Bonjean, and E.S, Johnson. 2004. The influence of tropical instability waves on phytoplankton blooms in the wake of the Marquesas Islands during 1998 and on the currents observed during the drift of the Kon-Tiki in 1947. Geophysical Research Letters 31:L23307, doi:10.1029/2004GL021637.

Lluch-Cota, D.B. 2002. Satellite measured interannual variability of coastal phytoplankton pigment in the tropical and subtropical eastern Pacific. Continental Shelf Research 22:803-820.

McClain, C.R., M.L. Cleave, G.C. Feldman, W.W. Gregg, S.B. Hooker, and N. Kuring. 1998. Science quality SeaWiFS data for global biosphere research. Sea Technology 39:10-16.

McClain, C.R., J.R. Christian, S.R. Signorini, M.R. Lewis, I. Asanuma, D. Turk, and C. DupouyDouchement. 2002. Satellite ocean color observations of the tropical Pacific Ocean. Deep Sea Research II 49:2,533-2,560.

Michaelsen, J., X. Zhang, and R.C. Smith. 1988. Variability of pigment biomass in the California current system as determined by satellite imagery: 2. Temporal variability. Journal of Geophysical Research 93:10,883-10,896.

Monger, B., C. McClain, and R. Murtugudde. 1997. Seasonal phytoplankton dynamics in the eastern tropical Atlantic. Journal of Geophysical Research 102:12,389-12,411.

Moore, J.K., and M.R. Abbott. 2000. Phytoplankton chlorophyll distributions and primary production in the Southern Ocean. Journal of Geophysical Research 105:28,709-28,722.

Muller-Karger, F.E., J.J. Walsh, R.H. Evans, and M.B. Meyers. 1991. On the seasonal phytoplankton concentration and sea surface temperature cycles of the Gulf of Mexico as determined by satellites. Journal of Geophysical Research 96:12,645-12,665.

Riley, G.A. 1947. Factors controlling phytoplankton populations on Georges Bank. Journal of Marine Research 6:54-73.

Ryan, J.P., J. A. Yoder, and P. C. Cornillon. 1999. Enhanced chlorophyll at the shelfbreak of the Mid-Atlantic Bight and Georges Bank during the spring transition. Limnology and Oceanography 44:1-11.

Ryan, J.P., P.S. Polito, P.G. Strutton, and F.P. Chavez. 2002. Unusual large-scale phytoplankton blooms in the equatorial Pacific. Progress in Oceanography 55:263-285.

Sackmann, B., L. Mack, M. Logsdon, and M.J. Perry. 2004. Seasonal and inter-annual variability of SeaWiFS-derived chlorophyll a concentrations in waters off the Washington and Vancouver Island coasts, 1998-2002. Deep-Sea Research II 51:945-965.

Sakamoto, C.M., D.M. Karl, H.W. Jannasch, R.R. Bidigare, R.M. Letelier, P.M. Walz, J.P. Ryan,
P.S. Polito, and K.S. Johnson. 2004. Influence of Rossby waves on nutrient dynamics and the plankton community structure in the North $\mathrm{Pa}$ cific subtropical gyre. Journal of Geophysical Research 109:C05032, doi:10.1029/2003JC001976.

Schollaert, S.E., T. Rossby, and J.A. Yoder. 2004. Gulf Stream cross-frontal exchange: Possible mechanisms to explain inter-annual variations in phytoplankton chlorophyll in the Slope Sea during the SeaWiFS years. Deep-Sea Research II 51:173-188.

Signorini, S.R., R.G. Murtugudde, C.R. McClain, J.R. Christian, J. Picaut, and A.J. Busalacchi. 1999. Biological and physical signatures in the tropical and subtropical Atlantic. Journal of Geophysical Research 104:18,367-18,382.

Smith, R.C., X. Zhang, and J. Michaelsen. 1988. Variability of pigment biomass in the California Current system as determined by satellite imagery: 1. Spatial variability. Journal of Geophysical Research 93:10,863-10,882.

Strub, P.T., C. James, A.C. Thomas, and M.R. Abbott. 1990. Seasonal and non-seasonal variability of satellite derived surface pigment concentration in the California Current, Journal of Geophysical Research 95:11,501-11,530.

Sverdrup, H.U. 1953. On conditions for the vernal blooming of phytoplankton. Journal du Conseil International pour l'Exploration de la Mer 18:287-295.

Thomas, A.C., and P.T. Strub. 1990. Seasonal and interannual variability of pigment concentrations across a California current frontal zone. Journal of Geophysical Research 95:13,02313,042 .

Thomas, A., and P.T. Strub. 2001. Cross-shelf phytoplankton pigment variability in the California Current. Continental Shelf Research 21:1,1571,190 .

Thomas, A.C., F. Huang, P.T. Strub, and C. James. 1994. Comparison of the seasonal and interannual variability of phytoplankton pigment concentration in the Peru and California Current systems. Journal of Geophysical Research 99:7,355-7,370.

Thomas, A.C., M.E. Carr, and P.T. Strub. 2001a. Chlorophyll variability in eastern boundary currents. Geophysical Research Letters 28:3,4213,424 .

Thomas, A.C., J.L. Blanco, M.E. Carr, P.T. Strub, and J. Osses. 2001b. Satellite-measured chlorophyll and temperature variability off northern Chile during the 1996-1998 La Niña and El Niño. Journal of Geophysical Research 106:899-915.

Thomas, A.C., D.W. Townsend, and R. Weatherbee. 2003. Satellite-measured phytoplankton variability in the Gulf of Maine. Continental Shelf Research 23:971-989.

Thomas, A.C., D.W. Townsend, and R. Weatherbee. 2004. Erratum to "Satellite-measured phy- toplankton variability in the Gulf of Maine”. (Continental Shelf Research 23 [2003] 971-989), Continental Shelf Research 24:293-294.

Uz, B.M., and J.A. Yoder. 2004. High frequency and mesoscale variability in SeaWiFS chlorophyll imagery and its relation to other remotely sensed oceanographic variables. Deep-Sea Research II 51:1,001-1,017.

Uz, M., J.A. Yoder, and V. Osychny. 2001. Global remotely sensed data supports nutrient enhancement by eddies and planetary waves. Nature 409:597-600.

Weeks, S.J., and F.A. Shillington. 1994. Interannual scales of variation of pigment concentrations from coastal zone color scanner data in the Benguela upwelling system and the Subtropical Convergence zone south of Africa. Journal of Geophysical Research 99:7,385-7,399.

Wilson, C., and D. Adamec. 2001. Correlations between surface chlorophyll and sea surface height in the tropical Pacific during the 1997-1999 El Niño-Southern Oscillation event. Journal of Geophysical Research 106:31,175-31,188.

Yoder, J.A. and M.A. Kennelly. 2003. Seasonal and ENSO variability in global ocean phytoplankton chlorophyll derived from 4 years of SeaWiFS measurements. Global Biogeochemical Cycles 17(4):1112, doi:10.1029/2002GB001942.

Yoder, J.A., W.E. Esaias, G.C. Feldman, and C.R. McClain. 1988. Satellite ocean color-status report. Oceanography 1:18-20.

Yoder, J.A., C.R. McClain, G.C. Feldman, and W.E. Esaias. 1993. Annual cycles of phytoplankton chlorophyll concentrations in the global ocean: A satellite view. Global Biogeochemical Cycles 7:181-194.

Yoder, J.A., J.E. O’Reilly, A.H. Barnard, T.S. Moore, and C.M. Ruhsam. 2001. Variability in Coastal Zone Color Scanner (CZCS) chlorophyll imagery of ocean margin waters off the U.S. East Coast. Continental Shelf Research 21:1,1911,218 .

Yoder, J.A., S.E. Schollaert, and J.E. O'Reilly. 2002. Climatological phytoplankton chlorophyll and sea-surface temperature patterns in continental shelf and slope waters off the Northeast U.S. coast. Limnology and Oceanography 47:672-682. 